\title{
Isolation of ammonium- and nitrite-oxidizing bacterial strains from soil, and their potential use in the reduction of nitrogen in household waste water
}

\author{
Abad Rodríguez Rodríguez ${ }^{1}$, Silvia Mau Inchaustegui ${ }^{1}$, Lilliana Piedra Castro ${ }^{1}$, Ricardo Jiménez \\ Montealegre $^{1} \&$ Juan Pablo Herrera Vargas ${ }^{2}$ \\ 1. Escuela de Ciencias Biológicas, Facultad de Ciencias Exactas y Naturales, Universidad Nacional, Heredia, Costa \\ Rica; jorengeth.rodriguez.rodriguez@una.cr, silvyamau@gmail.com, lilliana.piedra.castro@una.cr, \\ ricardo.jimenez.montealegr@una.cr \\ 2. INISEFOR, Instituto de Investigaciones y Servicios Forestales, Facultad de Ciencias de la Tierra y el Mar, Universidad \\ Nacional, Heredia, Costa Rica; jphv11@gmail.com
}

Received 07-X-2016. Corrected 28-VI-2017. Accepted 31-VII-2017.

\begin{abstract}
Currently, nitrogen has become the main element of water pollution, causing riverine, lacustrine and coastal eutrophication. The continuous contamination of aquifers and the absence of planned water resource utilization, boost its scarcity, and has been the only way in which our societies become aware of the urgent need to process the generated wastewater. The objective of this research was to evaluate the nitrifying capacity of different autochthonous bacterial isolates from soils from nearby sources of domestic wastewater drainage. For this, bacteria were isolated from Pirro River, contaminated with nitrogen of domestic sewage. Nitrifying bacteria were counted by serial dilution and agar plates, and were isolated until obtaining axenic colonies. These were identified by biochemical batteries or genetic sequencing, and the quantification of their nitrifying capacity was obtained by the methods 4500- NH4 + -F and 4500-NO-2-B, all between September 26, 2011 and March 16, 2014. A total of seven strains of nitrifying microorganisms were isolated and purified, including four Streptomyces sp., one Pseudomonas putida, one Sphingomonas sp. and one Aeromonas sp. We found that there were $2.23 \times 10^{5} \mathrm{UFC} / \mathrm{g}$ of soil of ammonium oxidizing bacteria and $2.2 \times 10^{4} \mathrm{CFU} / \mathrm{g}$ of soil of nitrite oxidizing bacteria in the samples. The quantification of the nitrifying capacity of the strains by colorimetric methods, determined that the maximum ammonium removal capacity was $0.050 \mathrm{mg} \mathrm{N} / \mathrm{L} /$ day and $0.903 \mathrm{mg}$ $\mathrm{N} / \mathrm{L} /$ day of nitrite. The collection of few strains of nitrifying organisms and a low CFU count, can be attributed to the technique used, since this only recovers $1 \%$ of the microorganisms present in a sample, which, however, is acceptable for studies which main purpose is to obtain cultivable microorganisms. Future research should consider removal tests with higher ammonium and nitrite levels, to find the maximum capacity of the isolated microorganisms, and evaluate their potential use in wastewater treatment systems. Rev. Biol. Trop. 65 (4): $1527-$ 1539. Epub 2017 December 01.
\end{abstract}

Key words: nitrification, $\mathrm{AOB}, \mathrm{NOB}$, soil, bacterial isolation, removal.

Water pollution implies limitations of its use, with the levels of these limitations depending on whether the water is for human consumption, recreational or agricultural activities, or for aquaculture (Cervantes, Pérez, \& Gómez, 2000). Pollution may be caused by natural phenomena or may stem from human activities (Helmer \& Hespanhol, 1997).

One of the most important water pollutants is nitrogen, agricultural and industrial activities have increased by almost twice the concentration of nitrogen fixed annually in the biosphere, and a great amount of that nitrogen reaches different water systems in the form of ammonium, nitrates and nitrites, causing toxicity for aquatic organisms, and environmental alterations such as eutrophication (Cervantes et al., 2000).

Physical, chemical and biological processes have been developed during the last few decades to treat waste waters. Each one of these 
is characterized by a series of limitations in terms of their level of applicability, efficiency, and cost (Templeton \& Butler, 2011).

An alternative for reducing nitrogen concentration is the generation of treatment strategies using microorganisms that can reduce the load of this element. One of these strategies is using nitrification, which is an aerobic process carried out by gram-negative lithoautotrophic microorganisms that belong to several families, that do not sporulate, and may be spherical, rod-shaped, or spiral (Cervantes et al., 2000; Fiencke, Spieck, \& Bock, 2005; Spieck \& Bock, 2005).

The nitrifying process in a microorganism takes place in two phases: 1) oxidation of ammonium to nitrite, and 2) oxidation of the nitrite to nitrate. Microorganisms of different genera and species participate in each of these phases; the bacteria species that can directly convert ammonium to nitrate have not yet been identified. This oxidation is carried out by bacteria of the genera Nitrosomonas sp., Nitrosococcus sp., Nitrosospira sp., Nitrosolobus sp., and Nitrosovibrio sp. (Fiencke et al., 2005).

Likewise, in aquatic and terrestrial systems, not only autotrophic bacteria carry out the nitrification process; there are also other heterotrophic organisms that can do so, such as the Arthrobacter, Azotobacter gender, and bacterial species such as Pseudomonas fluorescens, and Aerobacter aerogenus, and fungi of Aspergillus, Penicillium, and Neurospora genders. Some Actinomycetes use an organic carbon source for oxidizing ammonium to nitrate, thus contributing almost $10 \%$ of total nitrification in some soils and aquatic environments (Obaton, Amarger, \& Alexander, 1968; Witzel \& Overbeck, 1979; Bitton, 2005; Eldor, 2007).

The selection of biological processes for treating waste waters obviously have their origins in the biogeochemical cycles that take place in nature, and are mainly aimed at trying to control the environment and conditions of microorganisms to maximize the speed of conversion of polluting substrates into harmless products (Garza, Mata, Barbosa, \& Rodríguez, 2001).
In this way, microbial bioremediation of water contaminated by nitrogenous compounds can be carried out through the application of native nitrifying and denitrifying microorganisms that use forms of inorganic nitrogen or ammonium produced by human activities (Benavides, Quintero, \& Ostos, 2006). The search for specific microorganisms is important mainly for determining their intrinsic potential for use in strategies for bioremediation of waste water (Garza et al., 2001).

The present study is intended to contribute to the development of new technologies for environmental protection and restoration, encountering an additional tool that can reduce river pollution by nitrogen-rich compounds which cause health, aesthetic, and environmental problems, constituting an economic, efficient, and clean strategy derived from Costa Rican biodiversity.

\section{MATERIALS AND METHODS}

Study site: The soil sample for isolation of nitrifying bacteria was taken in the morning of the $28 / 09 / 2011$, this corresponds to the rainy season, from a site of direct discharge of household waste water, from the Jardines Universitarios housing development, into a collecting pipe or ditch in the bed of the Pirro River, in the surroundings of Universidad Nacional (9॰59'999" N - 8406'476” W), at 1168 masl (Fig. 1).

Laboratory work was carried out in the Microbiology Laboratory, Biotechnology Laboratory, the Marine Aquaculture Laboratory of the Biological Sciences School of the Universidad Nacional, and in the Soil Analysis Laboratory of INISEFOR. Sampling and experimental dates were from September 26, 2011 to March 16, 2014.

Soil sampling: Sampling in the selected site was based on a previous analysis of physical-chemical variables, which confirmed a high concentration of total nitrogen. The sample was taken from soil that was in immediate contact with soapy water, obtaining a representative 


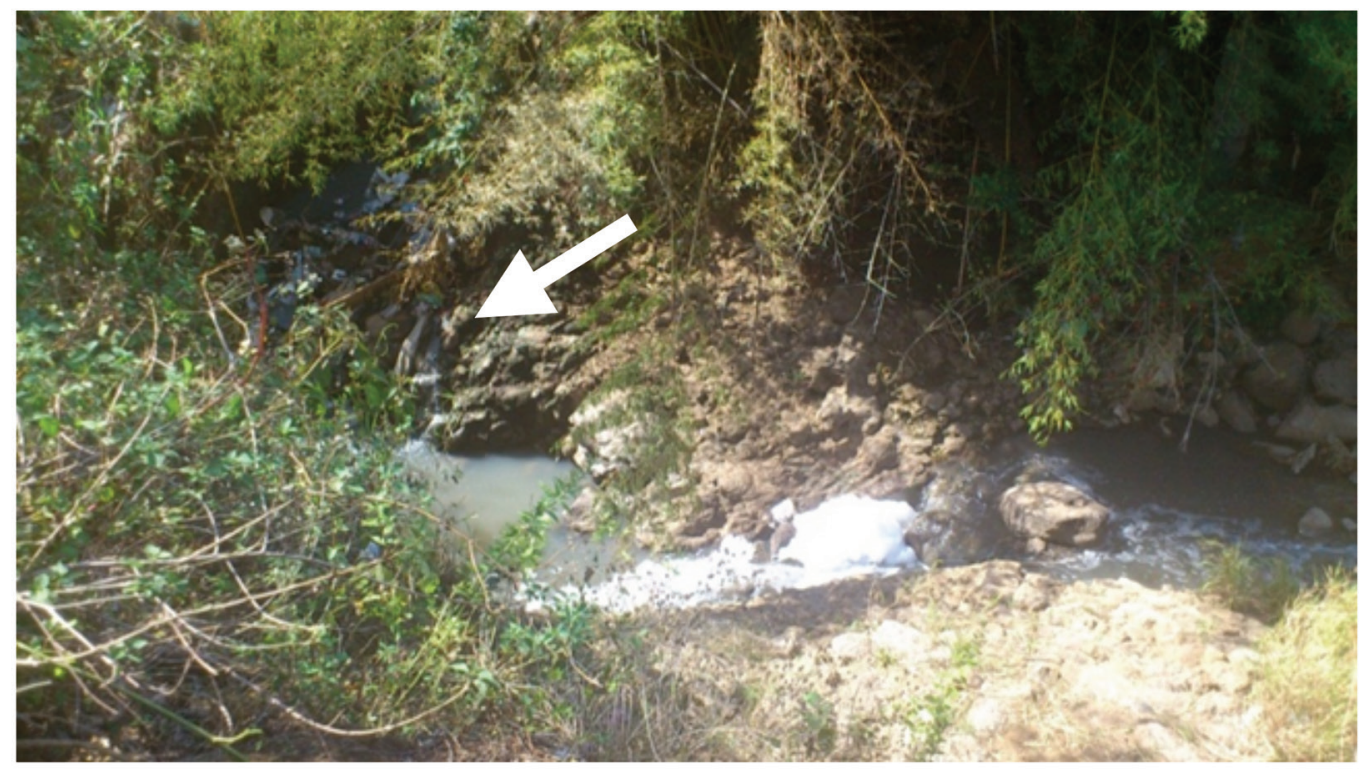

Fig 1. White arrow indicates the sampling site on the Pirro River.

sample of the site by taking a portion ( $30 \mathrm{~g})$ of the sample, from each side of the residual effluent, which ends up in the Pirro riverbed. Finally, this sample was stored in an airtight and sterile $500 \mathrm{~mL}$ erlenmeyer to be taken immediately to the laboratory to be processed.

Soil homogenization: During the process of isolating and quantifying nitrifying bacteria, a previous culture was created in an enriched and selective medium with ammonium or nitrite, together with bicarbonate as a carbon source, which could last for minutes, hours or days, since these bacteria grow slowly due to the low energy yield of the process (Fiencke et al., 2005; Spieck \& Bock 2005; Eldor, 2007; Madigan, Martinko, Dunlap, \& Clark, 2009).

A $10 \mathrm{~g}$ of soil was weighed out for the isolation of the ammonium-oxidizing bacteria (AOB), and another $10 \mathrm{~g}$ sample was weighed out for nitrite-oxidizing bacteria (NOB). The samples were suspended in Erlenmeyer flasks with $90 \mathrm{~mL}$ of liquid mineral medium, and shaken at $120 \mathrm{rpm}$ for 30 minutes at room temperature in an orbital shaker; at the end of this process, they were shaken in a
Vortex shaker for 30 seconds to ensure complete soil homogenization.

The liquid mineral medium consisted of $0.1 \mathrm{~g} \mathrm{MgSO}_{4}$ x $7 \mathrm{H}_{2} \mathrm{O}, 13.5 \mathrm{~g} \mathrm{Na}_{2} \mathrm{HPO}_{4}, 0.7 \mathrm{~g}$ $\mathrm{KH}_{2} \mathrm{PO}_{4}, 0.01 \mathrm{~g}$ anhydrous $\mathrm{FeCl}_{3}, 0.18 \mathrm{~g} \mathrm{CaCl}_{2}$ x $2 \mathrm{H}_{2} \mathrm{O}, 0.5 \mathrm{~g}\left(\mathrm{NH}_{4}\right)_{2} \mathrm{SO}_{4}$ and $0.5 \mathrm{~g} \mathrm{NaHCO}_{3}$ (modified from Spieck \& Bock, 2005) for the AOB, while for the NOB ammonium sulphate was replaced by $0.5 \mathrm{~g}$ of $\mathrm{NaNO}_{2}$ (modified from Spieck \& Bock, 2005); everything was dissolved in $1000 \mathrm{~mL}$ of distilled water, and final $\mathrm{pH}$ was adjusted to 7.5.

Total aerobic count of nitrifying bacteria: Serial 10 -fold dilutions were made from the homogenized soil in a liquid mineral medium corresponding to each type of bacteria, ranging from $10^{-1}$ to $10^{-5}$; each dilution was inoculated in duplicate into Petri plates with $0.1 \mathrm{~mL}$, and $20 \mathrm{~mL}$ of mineral agar medium with $15 \mathrm{~g}$ of Agar-Agar and the same composition as the liquid medium was then poured onto each plate for each type of bacteria. The media were incubated at room temperature until growth was observed in most of the plates. 
The dilutions that displayed growth of between 25 and 250 UFC were selected to quantify the colonies, and the calculation was made taking into account the titer of the dilution and the amount of inoculum used. The results were expressed in UFC/g of soil.

Isolation and identification of native nitrifying bacterial consortia: Based on the growth observed in the count of nitrifying bacteria, isolation and purification of native bacterial consortia were carried out through reseeding in a minimal mineral agar medium with a composition of $0.66 \mathrm{~g} \mathrm{~K}_{2} \mathrm{HPO}_{4} \times 3 \mathrm{H}_{2} \mathrm{O}$, $1 \mathrm{~g} \mathrm{NH}_{4} \mathrm{Cl}, 2 \mathrm{~g} \mathrm{NaSO}_{4}, 0.2 \mathrm{~g} \mathrm{MgSO}_{4}$ x $7 \mathrm{H}_{2} \mathrm{O}$, and $15 \mathrm{~g}$ of Agar-Agar in $1000 \mathrm{~mL}$ of distilled water, adjusting the final $\mathrm{pH}$ to 7.5 .

The cultures were handled under the same growing conditions as those described for bacterial counts of nitrifying bacteria, and necessary reseedings were carried out until pure strains were obtained in a solid minimal mineral agar medium. The pure strains that were components of the native consortia were replanted in culture media of mineral minimal agar in an inclined tube, seeking to obtain sufficient growth for complete identification, and to keep them viable (Benavides et al., 2006).

The purified strains were Gram stained. In addition, the isolated microorganisms were tested to obtain their biochemical profiles using Biolog GN2 or GP2 microplates; those that could not be identified based on their biochemical profile were identified through genetic sequencing, paying for the services to the Bacteriology Laboratory at the Microbiology Faculty of the University of Costa Rica.

Culturing systems: Nitrifying cultures were produced in closed systems or in Batch systems implemented in Erlenmeyer flasks $(500 \mathrm{~mL})$ with sterile air pumping, for each type of ammonium-oxidizing bacteria (AOB) and nitrite-oxidizing bacteria (NOB) culture, each one with one replication (AOB-1, AOB-2; NOB-1, NOB-2) and $300 \mathrm{~mL}$ of medium. Each flask was inoculated with $1 \mathrm{~mL}$ of bacterial suspension in sterile saline solution, at a concentration of $0.5 \mathrm{McF}$ arland $\left(1.5 \times 10^{8} \mathrm{UFC} / \mathrm{mL}\right)$, and were kept in the dark because of the sensitivity of these organisms to light.

Cultures were produced with water from the Pirro River, sterilized three times, and filtered through paper using a Buchner and Kitasato system in the case of the AOB. For $\mathrm{NOB}$, before the sample was sterilized and filtered, it was subjected to aeration for $24 \mathrm{~h}$ to remove ammonium, after which this sample was supplemented with $0.2 \mathrm{~g} / \mathrm{L}$ of $\mathrm{NaNO}_{2}$. The $\mathrm{pH}$ of the river water was used.

The assay was carried out in a single cycle at room temperature. For AOB, feeding lasted for 30 days, and 22 days for NOB. During this time, samples of $10 \mathrm{~mL}$ were taken every eight days for analysis (Jarpa et al., 2007).

Analytical methods: Quantification during reduction of substrate concentrations $\left(\mathrm{NH}_{4}^{+}\right.$ y $\left.\mathrm{NO}_{2}^{-}\right)$and increases in the products $\left(\mathrm{NO}_{2}^{-}\right)$ was carried out using the $4500-\mathrm{NH}_{4}^{+}-\mathrm{F}$ phenate method for ammonium, and the $4500-\mathrm{NO}_{2}^{-}$- $\mathrm{B}$ colorimetric method for nitrite in samples taken from the systems every eight days (Eaton, Clesceri, \& Greenberg, 1995).

Substrate biodegradation: Biodegradation speeds were calculated using the slope of a straight line through the quotient of increases in the concentration of products or consumption of substrata and time, considering the points between which a significant change was observed in the behavior of the straight line:

$$
\mathrm{rx}=\Delta(\mathrm{X}) / \Delta \mathrm{t}
$$

Where rx is the maximum production or substrata consumption speed for both $\mathrm{AOB}$ and $\mathrm{NOB}$ ( $\mathrm{mg} \mathrm{N} / \mathrm{L} /$ day), $\mathrm{X}$ is the concentration of substrate consumed or product generated $(\mathrm{mg} \mathrm{N} / \mathrm{L})$, and $\mathrm{t}$ is the time of operation of the culture (days) (Jarpa et al., 2007).

A two-way multifactor analysis of variance (ANOVA) was carried out using the Statgraphics Centurion XV statistical package on the ammonium and nitrite data from each 
strain to determine whether the effect is due to bacterial action or time.

A one-way ANOVA was performed with a non-parametric a posteriori Kruskal-Wallis test with ammonium and nitrite removal data from the first week of the assay, to determine whether there was a difference between the activities of the strains.

\section{RESULTS}

Counting, isolation and identification of native nitrifying bacterial consortia: Adequate growth of the organisms was observed on the plates that were initially inoculated with the dissolutions of soil samples which were incubated at $25{ }^{\circ} \mathrm{C}$. A total aerobic count was carried out for ammonium-oxidizing bacteria (AOB), obtaining a concentration of $2.23 \mathrm{x}$ $10^{5} \mathrm{UFC} / \mathrm{g}$ of soil, while for nitrite-oxidizing bacteria (NOB) the concentration obtained was $2.2 \times 10^{4} \mathrm{UFC} / \mathrm{g}$ of soil.

The colonies replicated in minimal mineral agar medium grew on the plates 12 days after replication. Some of the originally replicated strains were lost in the process, and other apparently different strains were observed, which were separated and purified again. Finally, seven purified strains were selected to be identified and to carry out the nitrogen removal bioassays in waste waters.

To initially identify the selected strains, the Gram staining showed four Gram Positive strains, and three Gram Negative strains.

Furthermore, with the use of the biochemical profile of isolated strains (BIOLOG GP2 and GN2 microplates), we determined that the Yellow C4 strain was Sphingomonas sp., the C6.1 strain Aeromonas sp., and the C9 strain was Pseudomonas putida.

The genetic sequencing of the $16 \mathrm{~S}$ ribosomal RNA in the strains that were not identified through biochemical profiles, showed that the White C4 strain, C6.2 strain, C7.1 strain, and C8 strain were of the genus Streptomyces, and their identification at the species level was not possible; in this work they were therefore reported at the genus level as Streptomyces sp.

Quantification of nitrifying capacity of the isolated strains: A decrease was observed in the levels of ammonium and an increase in nitrite concentration in all strains, which is in agreement with the expected scenario (Fig. 2 and Fig. 3). It was determined that the change or decrease in ammonium concentration was statistically supported by the activity of the bacteria $(\mathrm{F}=5.39 ; \mathrm{P}=0.00)$, and by time $(\mathrm{F}=33.08$; $\mathrm{P}=0.00)$. Nitrite production was likewise

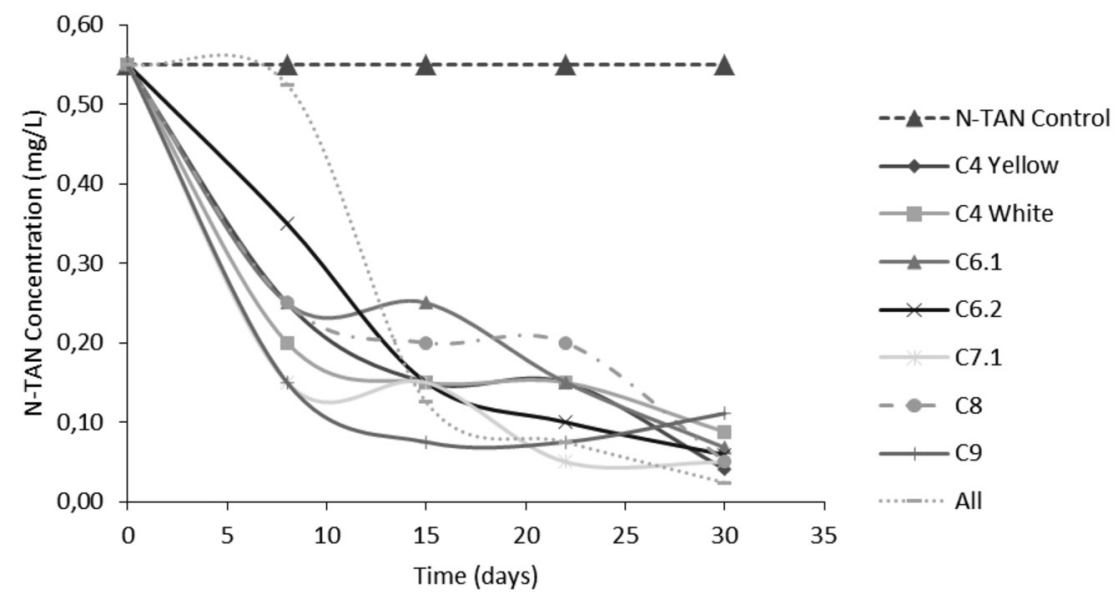

Fig. 2. TAN (Total Ammoniacal Nitrogen, $\mathrm{N}_{-} \mathrm{NH}_{3}+\mathrm{N}_{-} \mathrm{NH}_{4}^{+}$) consumption of bacterial strains isolated from soil of the Pirro River. 


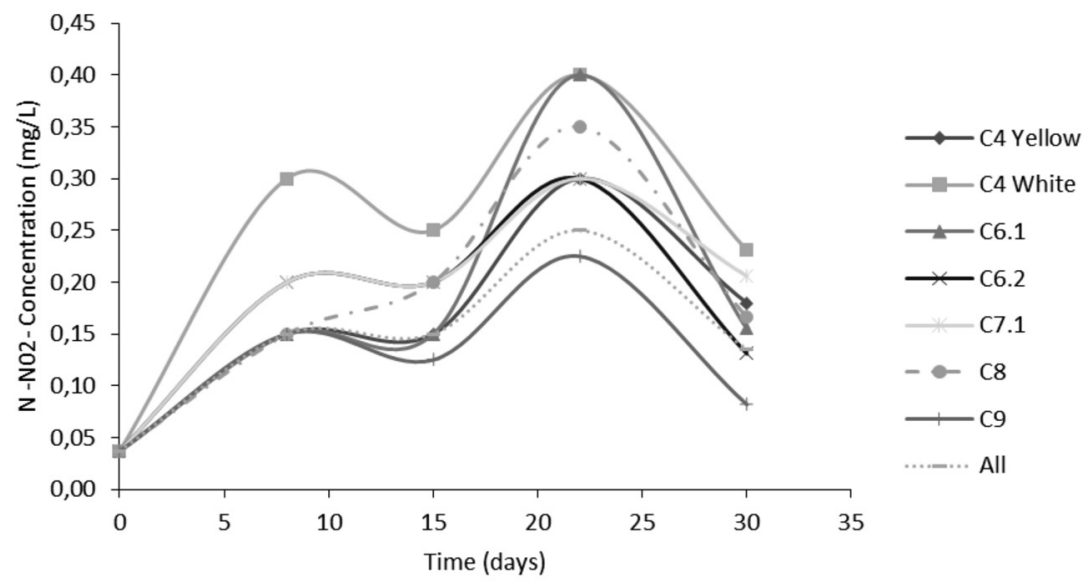

Fig. 3. Nitrite $\left(\mathrm{N}^{-\mathrm{NO}_{2}}{ }^{-}\right)$production from bacterial strains isolated from the soil of the Pirro River.

TABLE 1

Nitrogen removal rate in the form of TAN

$\left(\mathrm{N}-\mathrm{NH}_{3}+\mathrm{N}-\mathrm{NH}_{4}^{+}\right)$from seven bacterial strains isolated from the soil of the Pirro River

\begin{tabular}{lc}
\multicolumn{1}{c}{ Strain } & Removal $(\mathrm{mg} \mathrm{N} / \mathrm{L} /$ day $)$ \\
Yellow C4 & 0.038 \\
White C4 & 0.044 \\
C6.1 & 0.038 \\
C6.2 & 0.025 \\
C7.1 & 0.050 \\
C8 & 0.038 \\
C9 & 0.050 \\
All & 0.028 \\
\hline
\end{tabular}

the result of the action of bacteria $(\mathrm{F}=10.82$; $\mathrm{P}=0.00)$ and time $(\mathrm{F}=32.92 ; \mathrm{P}=0.00)$.

The substrate (ammonium) biodegradation capacity calculated for all the strains based on data from the first week of the assay (day eight), showed that strains C7.1 and C9 were the most efficient, with a removal capacity of $0.050 \mathrm{mg} \mathrm{N} / \mathrm{L} /$ day (Table 1). No statistically significant differences were found between the removal capacities of the strains used (w: 11.04; $\mathrm{gl}=8.10 ; \mathrm{P}=0.19$ ) during the first week. The $\mathrm{R}^{2}$ value for the nitrite production curve was presented through the point of the $22^{\text {nd }}$ day.

TABLE 2

Concentration change of nitrogen in the form of TAN $(\mathrm{N}-\mathrm{NH} 3+\mathrm{N}-\mathrm{NH} 4+)$ and nitrite $(\mathrm{N}-\mathrm{NO} 2-)$ at the $8^{\text {th }}$ day of the assay

\begin{tabular}{|c|c|c|c|c|}
\hline Strain & Initial TAN & $8^{\text {th }}$ day TAN & Initial $\mathrm{N}^{-\mathrm{NO}_{2}}{ }^{-}$ & $8^{\text {th }}$ day $\mathrm{N}-\mathrm{NO}_{2}^{-}$ \\
\hline Yellow C4 & 0.55 & 0.25 & 0.04 & 0.15 \\
\hline White C4 & 0.55 & 0.20 & 0.04 & 0.30 \\
\hline C6.1 & 0.55 & 0.25 & 0.04 & 0.15 \\
\hline C6.2 & 0.55 & 0.35 & 0.04 & 0.20 \\
\hline C7.1 & 0.55 & 0.15 & 0.04 & 0.20 \\
\hline $\mathrm{C} 8$ & 0.55 & 0.25 & 0.04 & 0.15 \\
\hline C9 & 0.55 & 0.15 & 0.04 & 0.15 \\
\hline Strain & Initial $\mathrm{N}_{-} \mathrm{NO}_{2}^{-}$ & $8^{\text {th }}$ day $\mathrm{N}-\mathrm{NO}_{2}^{-}$ & & \\
\hline White C4 & 35.50 & 28.28 & & \\
\hline C7.1 & 35.50 & 34.51 & & \\
\hline $\mathrm{C} 8$ & 35.50 & 34.58 & & \\
\hline
\end{tabular}


Throughout the assay, the control treatment did not show any changes in ammonium concentration. In all the curves obtained for ammonium consumption, except one, the $\mathrm{R}^{2}$ values were above 0.70 , reaching a maximum value of 0.89 ; for nitrite production, all the values were higher than 0.78 , reaching a maximum of 0.96 (Fig. 4 and Fig. 5; Table 2).

Regarding nitrite consumption during bioassays, a decrease in the levels of nitrite was observed in all strains (Fig. 6; Table 2). It was found that statistically, the change or decrease in nitrite concentration, was not the result of bacterial activity $(\mathrm{F}=1.72 ; \mathrm{P}=0.2315)$ or time $(\mathrm{F}=1.29 ; \mathrm{P}=0.3364)$.

Nitrite substrate biodegradation capacity was calculated for all the strains based on data from the first week of the assay (day eight). It was found that the White $\mathrm{C} 4$ strain was more efficient, with a removal capacity of $0.903 \mathrm{mg}$ N / L / day (Table 3).

No statistically significant differences were found in the decrease of nitrite concentration in the first week between the treatments (w: $6.66 ; \mathrm{gl}=3.4 ; \mathrm{P}=0.08$ ). The $\mathrm{pH}$ of the medium as a result of ammonium consumption / transformation showed a decrease in all treatments, while this parameter remained constant for the control (Table 4).

In the case of the bioassay of nitrite $\left(\mathrm{N}-\mathrm{NO}_{2}{ }^{-}\right)$consumption / transformation, a rise in the $\mathrm{pH}$ of the medium was observed, while this parameter remained stable in the control during the assay (Table 5).
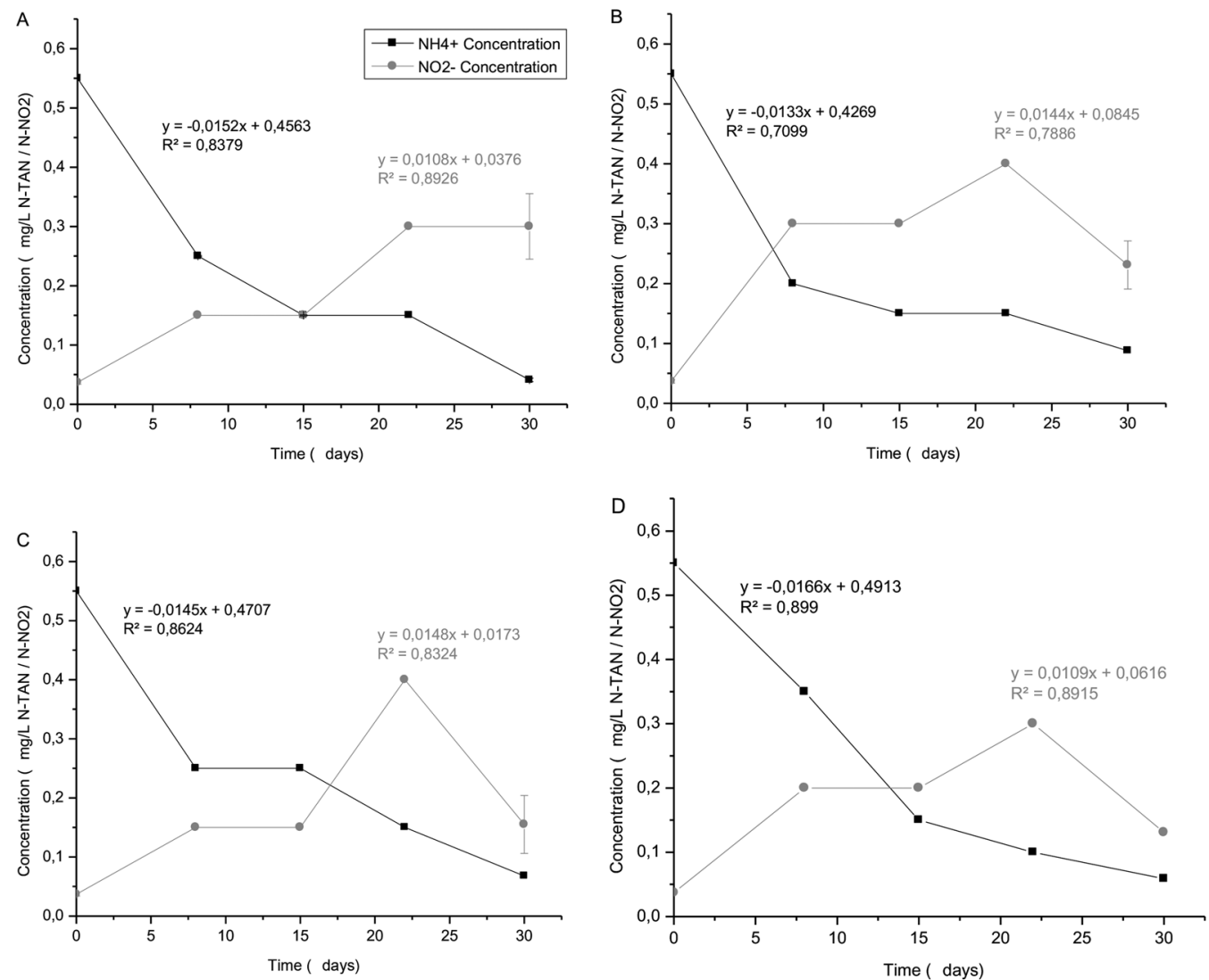

Fig. 4. Ammonium consumption and nitrite production $(\mathrm{mg} / \mathrm{L})$ in the Sphingomonas sp. (A), C4 Streptomyces sp. (B), Aeromonas sp. (C), and C6.2 Streptomyces sp. (D) strains. 

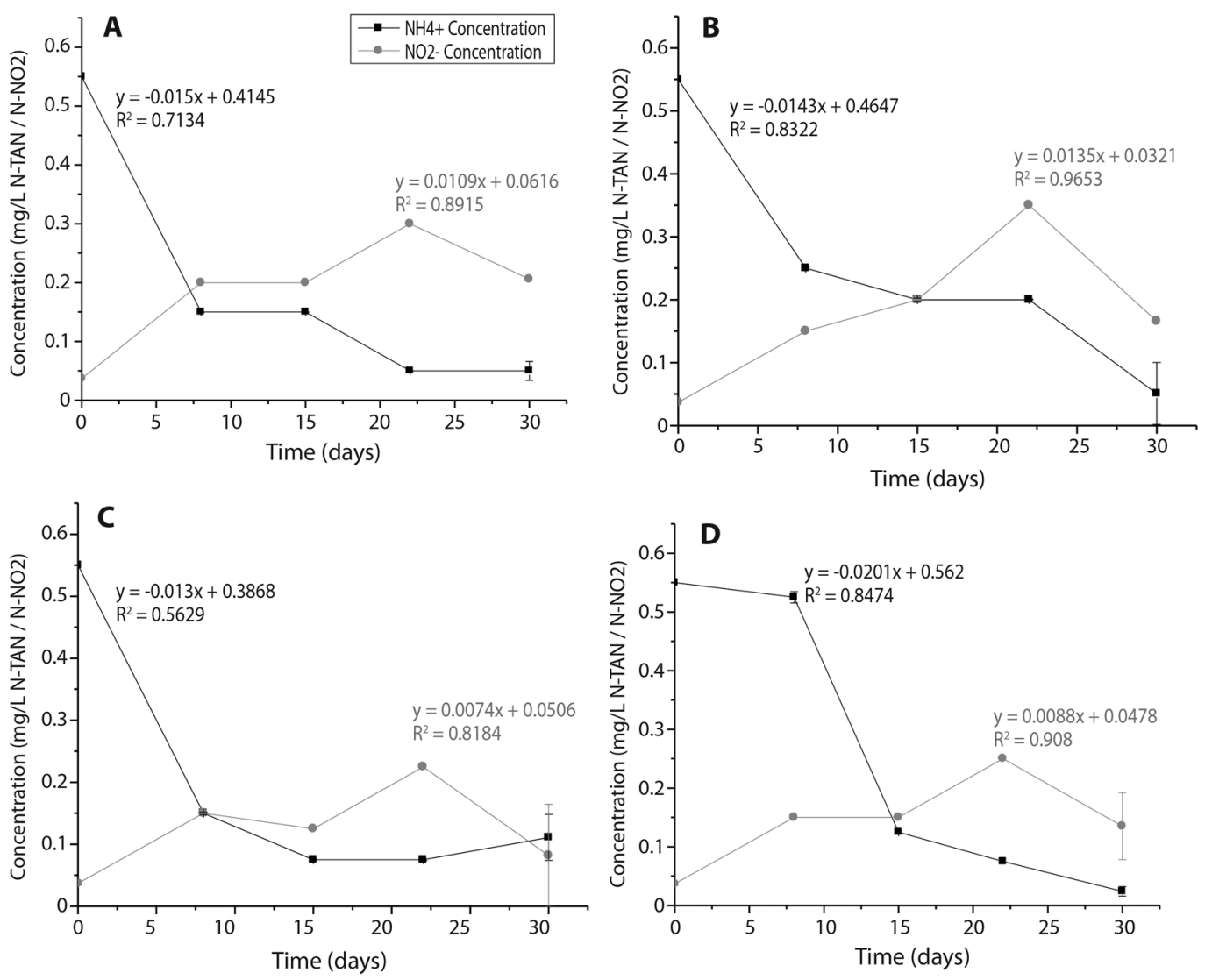

Fig. 5. Ammonium consumption and nitrite production $(\mathrm{mg} / \mathrm{L})$ in the C7.1 Streptomyces $\mathrm{sp}$. (A), C8 Streptomyces sp. (B), Pseudomonas putida (C) strains, and the (D) consortium.

TABLE 3

Nitrogen removal rate in terms of nitrite $\left(\mathrm{N}-\mathrm{NO}_{2}^{-}\right)$ for several bacterial strains isolated from soil samples of the Pirro River

\begin{tabular}{lc}
$\quad$ Strain & Removal (mg N/L/day) \\
White C4 & 0.903 \\
C7.1 & 0.124 \\
C8 & 0.115 \\
\hline
\end{tabular}

\section{DISCUSSION}

The shortest time of generation or division that has been found in a laboratory for nitrifying bacteria was seven hours for Nitrosomonas sp., and ten hours for Nitrobacter sp. (Spieck \& Bock, 2005); however, most known nitrifying microorganisms require several days or weeks to carry out this same process in natural environments, depending mostly on the type of substrate, the amount of oxygen in the water or soil, temperature, and $\mathrm{pH}$ (Spieck \& Bock, 2005; Werner \& Newton, 2005).

Given these low growth rates, determining or reliably estimating the number or size of populations, and the dynamics of the nitrifying populations in different environments, has been very difficult to achieve. For this reason, the number of nitrifying bacteria in an environment has been traditionally determined through the most probable number (MPN) technique, or through counting in a selective medium. However, as this work has shown, these techniques are time-consuming and exclude part of the real nitrifying population in the environment. 

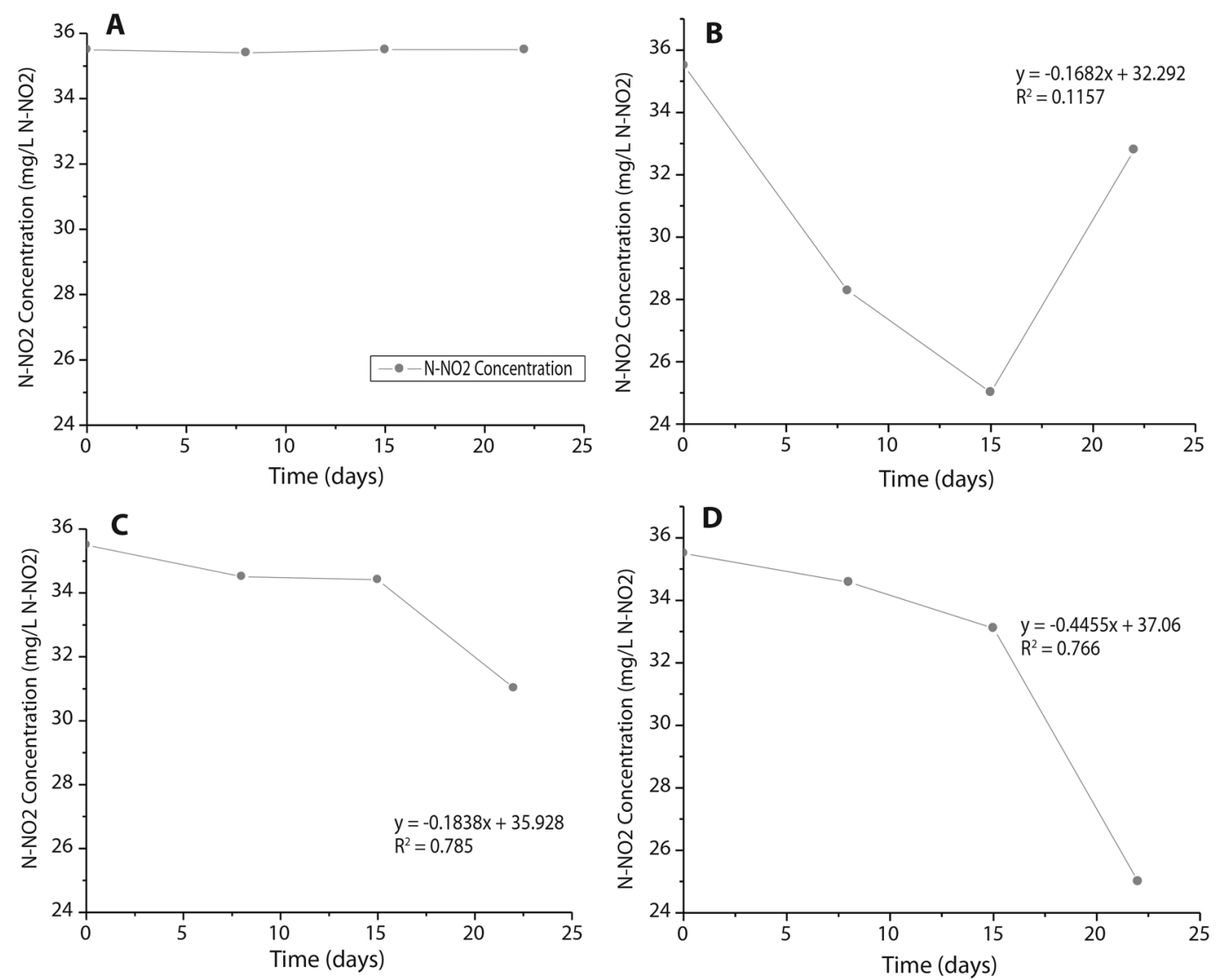

Fig. 6. Nitrite consumption during bioassays with the selected bacterial strains. Control (A), C4 Streptomyces sp. (B), C7.1 Streptomyces sp. (C), and C8 Streptomyces sp. (D).

Likewise, the composition of the medium and incubation conditions may have an effect, as it may be that when quantifying the nitrifying community, only a fraction of the community is taken into account (Fiencke et al., 2005; Werner \& Newton, 2005).
However, in spite of the foregoing, the plate count technique used, which usually only encounters around $1 \%$ of the total viable cells in the sample, is useful for comparative purposes, or when the research is focused on obtaining cultivable bacterial strains (Coleman, Crossley,

TABLE 4

$\mathrm{pH}$ values of different strains assayed in water from the Pirro River during the assay of ammonium consumption

\begin{tabular}{|c|c|c|c|c|c|}
\hline Strain/day & 0 & 8 & 15 & 22 & 30 \\
\hline Control & 9.2 & 9.2 & 9.2 & 9.2 & 9.2 \\
\hline C4 Streptomyces sp. & 9.2 & 9.12 & 9.1 & 8.55 & 8.55 \\
\hline Sphingomonas sp. & 9.2 & 9.13 & 8.85 & 8.56 & 8.56 \\
\hline C6.2 Streptomyces sp. & 9.2 & 9.2 & 9 & 8.62 & 8.75 \\
\hline Aeromonas sp. & 9.2 & 9 & 8.93 & 8.71 & 8.71 \\
\hline C8 Streptomyces sp. & 9.2 & 8.81 & 8.4 & 8 & 8.62 \\
\hline C7.1 Streptomyces sp. & 9.2 & 8.87 & 8 & 8.58 & 8.7 \\
\hline Pseudomonas putida & 9.2 & 8.9 & 8.63 & 8.38 & 8.36 \\
\hline Consortium & 9.2 & 8.9 & 8.75 & 8.7 & 7.74 \\
\hline
\end{tabular}


TABLE 5

$\mathrm{pH}$ values of the different strains assayed, and the control treatment for water from the Pirro River during the nitrite consumption assay

\begin{tabular}{|c|c|c|c|c|}
\hline Strain/day & 0 & 8 & 15 & 22 \\
\hline Control & 8.75 & 8.70 & 8.75 & 8.75 \\
\hline C4 Streptomyces sp. & 8.75 & 9.1 & 9.1 & 9.3 \\
\hline C8 Streptomyces sp. & 8.75 & 9.17 & 9.17 & 9.23 \\
\hline C7.1 Streptomyces sp. & 8.75 & 9.14 & 9.17 & 9.35 \\
\hline
\end{tabular}

\& Hendrix, 2004), as proposed in this work. Even though the amounts of $2.23 \times 10^{5} \mathrm{UFC} / \mathrm{g}$ of soil for ammonium-oxidizing bacteria, and $2.2 \times 10^{4} \mathrm{UFC} / \mathrm{g}$ of soil for nitrite-oxidizing bacteria are only a fraction of the actual population, these values provide some idea of the size of the population, permitting to obtain an amount of cultivable microorganisms to assay their nitrifying capacity.

The loss of strains experienced during the replication process from the original isolation to new plates is usual in all isolation processes; not all isolated strains are able to survive the process, mainly due to the loss of necessary co-factors found in the soil, which are not maintained during inoculation and replication in artificial mediums (Madigan et al., 2009).

Neither bacteria identified through Gram staining and biochemical profiling, not even those identified through sequencing of $16 \mathrm{~S}$ rRNA genes, yielded species with morphological, biochemical or genetic characteristics belonging to characteristic genera or recognized as lithoautotrophic nitrifying bacteria; instead, organisms belonging to the Streptomyces and Pseudomonas genus were isolated, both of which are known to carry out the nitrifying process heterotrophically (Bitton, 2005; Fiencke et al., 2005; Eldor, 2007).

This also happened with Aeromonas sp. and Sphingomonas sp. strains, which play a greater or lesser role in the nitrifying process, depending on environmental conditions, the nitrogen load, and the growth cycle phase in which they are encountered. Aeromonas sp. may use nitrite and reduce it to ammonium, or use intermediate stages such as hydroxylamine; Sphingomonas sp. may also use these intermediaries (Okpokwasili \& Eleke, 1997; Wehrfritz, Carter, Spiro \& Richardson, 1997;
Mohan, Schmid, Jetten, \& Cole, 2004; Park, Nam, Lee, \& Kim, 2009). It can be confirmed that they can make use of ammonium or nitrite substrates and of their intermediaries when analyzing databases of metabolic routes (Kanehisa Laboratories, 2013a, 2013b).

A wide range of bacteria are known to have the capacity to oxidize ammonium heterotrophically; however, this heterotrophic nitrifying process is not linked to cellular growth, which is the case in autotrophic nitrifying processes. This oxidation may be carried out through two metabolic routes: one which is present only in fungi, and another, very similar to autotrophic nitrification, in which heterotrophic microorganisms have an ammonium-monooxygenase enzyme, and one hydroxylamine oxidoreductase, similar to the autotrophic route, which oxidizes ammonium in a secondary manner, since these enzymes evolved to oxidize compounds such as propylene, benzene, phenol, methanol, and any other non-polar organic compound that serves as a source of carbon and energy (Bitton, 2005; Eldor, 2007).

To carry out the heterotrophic nitrifying process, these microorganisms require a source of carbon in the medium; however, the culture medium used in this research was a selective agar which did not contain any source of organic carbon. The only scenario which can accomplish this result is the finding of new strains of Actinomycetes, specifically Streptomyces sp. with the capacity to grow autotrophically, as reported by $\mathrm{Hu}$, Zheng, $\mathrm{Wu}$ and Yin (2005). These authors were able to isolate a strain of Streptomyces bikiniensis, which they called "A2", with the capacity to grow autotrophically in an inorganic mineral medium, such as that used in this study. In the literature cited, and the classification of bacteria 
with autotrophic nitrifying capacity, no genera other than those mentioned previously can be found with this characteristic.

On the other hand, the nitrifying process in consumption and production assays was carried out heterotrophically, as the water from the Pirro River, just as that from other fluvial systems, is polluted by high organic loads (Bitton, 2005; Madigan et al., 2009).

Every microorganism has its own physiological, metabolic and morphological characteristics which differentiate it from other species of the same genus, from different genera, and even from strains of the same species; at the same time, they may have characteristics that make them similar to each other, which have the evolutionary purpose of providing the variability or capacities necessary to be able to compete or adapt to the medium in which they are found (Madigan et al., 2009).

Probably because of these characteristics, no significant statistic differences were found between the strains in the assays, and their capacity for removing or using ammonium and nitrite as a source of energy. The same result was found when nitrite production was evaluated; since the strains were isolated from the same location, and assayed at the same concentrations as those of the energetic substrate, it was found that all of them have a similar capacity, probably because of their acquired adaptations to those conditions (Moat, Foster, \& Spector, 2002; Bitton, 2005; Eldor, 2007).

The strains showed a very similar capacity for biodegradation of the substratum, except for the White C4 strain, whose nitrite consumption exceeded by eight times the capacity of the other two strains, and by 18 times the capacity of the two strains with better ammonium removal capacity. This marked difference in removal capacity between the same strains, in assays of nitrite and ammonium, is probably due to the capacity of microorganisms to adapt their metabolisms to different substrate concentrations they use for their metabolism (Moat et al., 2002; Madigan et al., 2009).

In their research, $\mathrm{Hu}$ et al. (2005) were able to determine that the maximum removal capacity of this strain of Streptomyces bikiniensis was $0.22 \mathrm{mg} \mathrm{N} / \mathrm{L} /$ day, which is four times higher than the best performance obtained by Streptomyces isolated and used in this assay, and shows their possible potential for ammonium removal, when evaluated in a higher ammonium concentration.

For their part, Zhang, $\mathrm{Wu}$, Hao and $\mathrm{Yu}$ (2011), using a strain of Pseudomonas stutzeri YZN-001, determined that it may heterotrophically consume a minimum of $0.3 \mathrm{mg} \mathrm{N} / \mathrm{L} /$ hour in the form of ammonium. This is higher than the capacity calculated for Pseudomonas found in this study; however, it may grow in an autotrophic medium and carry out the oxidation of ammonium to nitrite.

Analysis of ammonium consumption and nitrite production showed that there is a coupling or simultaneous effect between consumption and production. As expected, a nitrite increase was observed as ammonium decreases, and there is no change or increase in nitrite concentration if ammonium is not consumed. Periods in which ammonium concentration did not decrease may be explained by several factors: the first is the fact that during week two (days 8 to 15), because of an error when setting up the ventilation system again after the system was sampled, the system was disconnected and some strains were not oxygenated. This lack of ventilation may have caused a temporary cessation or reduction of the nitrifying activity.

The level of dissolved oxygen in the medium is the most important factor in the dynamics of the nitrifying process; it is so critical that at least $2 \mathrm{mg} / \mathrm{L}$ of oxygen are required for the nitrifying process to be carried out successfully (Helmer \& Hespanhol, 1997; Bitton, 2005; Constantine, 2008; Templeton \& Butler, 2011).

In the case of the assay with the consortium, it was observed that compared to the rest of the assays, the ammonium concentration decrease was not as marked as the first eight days, and that this concentration decreased considerably through the second week, which may have been due to the fact that when making a suspension of all the strains and inoculating the assay medium, a process of competition, 
dominance or co-dominance in the medium began to establish (Madigan et al., 2009).

Due either to an intrinsic antagonism between some strains, or between all of them; for the production of antibiotic substances to eliminate the others; the creation of synergic relationships between two or more strains, or finally, because when preparing the suspensions, the bacteria were in different growth phases, with some of them growing more rapidly than others (for instance being in the exponential phase while others were in the Lag phase), making them less capable of competing in a new environment and against other microorganisms (Madigan et al., 2009).

In the individual graphics for nitrite consumption, a decrease in nitrite concentration is observed in all cases, which shows that the nitrite-oxidizing nitrifying process appears to be occurring. This conclusion is also supported by the observed increase in the $\mathrm{pH}$ of the medium, with the initial value of 8.75 rising to more than 9.3 as the days go by, due to the formation of nitrate (which is a stronger base than nitrite), leading to an increase in the $\mathrm{pH}$ of the medium (Essington, 2004). The variation observed in the last point of the strain C4 Streptomyces sp. may be explained by a mistake in the dilution process of the sample or in its measurement.

It may be concluded that the isolated bacteria assayed represent a future opportunity for improving environmental conditions of Costa Rican rivers, since these strains have the potential to be used for reducing ammonium and nitrite pollution in residual household waters. Given their demonstrated capacities, they are very promising candidates for use in the treatment of effluents through systems of artificial wetlands or conventional treatment systems.

\section{ACKNOWLEDGMENT}

To Norman Rojas dean of the Microbiology Faculty, University of Costa Rica, and Juan Ulloa Rojas, Coordinator of the Aquaculture Laboratory for the help provided.

\section{RESUMEN}

Aislamiento de cepas bacterianas oxidantes de
amonio y nitrito del suelo y su uso potencial en la reduc-
ción de nitrógeno en las aguas residuales domésticas. El suelo es la matriz fundamental donde suceden las reacciones químicas y biológicas que permiten el desarrollo de la vida en la tierra, y donde ocurren procesos fundamentales como la mineralización de los elementos y la fijación del nitrógeno. Hoy en día el nitrógeno se ha transformado en uno de los principales elementos contaminantes de los cuerpos de agua, causando consecuencias como la eutrofización de ríos, lago y costas. En los ambientes acuáticos, el nitrógeno puede ser encontrado en forma de amonio

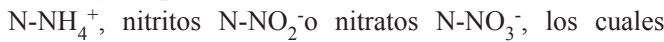
pueden ser utilizados por las bacterias nitrificantes amonio y nitrito oxidantes y desnitrificantes para su crecimiento y consecuente remoción. Esta investigación se planteó como objetivo evaluar la capacidad nitrificante de diferentes aislamientos bacterianos autóctonos, aislados de suelos cercanos a fuentes de vertido de aguas residuales de tipo doméstico para su potencial uso en sistemas de tratamiento de aguas residuales. Se realizó el recuento de bacterias nitrificantes por la técnica de dilución seriada y siembra en placas de agar mínimo mineral, su aislamiento por repique en placa hasta obtener colonias axénicas, su identificación por medio de baterías bioquímicas o secuenciación genética y la cuantificación de su capacidad nitrificante por los métodos $4500-\mathrm{NH}_{4}^{+}-\mathrm{F}$ y $4500-\mathrm{NO}_{2}^{-}$-B, entre el 26/09/2011 y 16/03/2014; las bacterias fueron aisladas de un punto del río Pirro contaminado con nitrógeno de aguas residuales de tipo doméstico. Se lograron aislar y purificar siete cepas de microorganismos nitrificantes entre las que se encuentran cuatro de Streptomyces sp., una de Pseudomonas putida, una de Sphingomonas sp. y una de Aeromonas sp. Se encontró que existen $2.23 \times 10^{5} \mathrm{UFC} / \mathrm{g}$ de suelo de bacterias amonio oxidantes y $2.2 \times 10^{4} \mathrm{UFC} / \mathrm{g}$ de suelo de las nitrito oxidantes. La cuantificación de la capacidad nitrificante de las cepas por medio de los métodos colorimétricos determinó que la capacidad máxima de remoción de amonio es de $0.050 \mathrm{mg} \mathrm{N} / \mathrm{L} /$ día y la de nitrito en 0.903 $\mathrm{mg}$ N/L/día. La obtención de pocas cepas de organismos nitrificantes y un bajo recuento de UFC se puede atribuir a la técnica empleada, ya que esta solo recupera un $1 \%$ de los microorganismos presentes en una muestras, lo cual sin embargo, es aceptable para estudios que tienen como objetivo la obtención de microorganismos cultivables. Se recomienda realizar ensayos de remoción con niveles de amonio y nitrito más altos para hallar la capacidad máxima de los microorganismos aislados.

Palabras clave: nitrificación, BAO, BNO, suelo, aislamiento bacteriano, remoción. 


\section{REFERENCES}

Benavides, J. L., Quintero, G. M., \& Ostos, O. L. (2006) Aislamiento e identificación de diez cepas bacterianas desnitrificantes a partir de un suelo agrícola contaminado con abonos nitrogenados proveniente de una finca productora de cebolla en la Laguna de Tota, Boyacá, Colombia. Nova-Publicación Científica, 4, 50-54.

Bitton, G. (2005). Wastewater microbiology ( $3^{\text {rd }}$ ed). New Jersey, USA: Wiley-Liss.

Cervantes, F., Pérez, J., \& Gómez, J. (2000). Avances en la eliminación biológica del nitrógeno de las aguas residuales. Revista Latinoamericana de Microbiología, 42, 73-82.

Coleman, D., Crossley, C. D. A., \& Hendrix, P. F. (2004) Fundamentals of soil ecology ( $2^{\text {nd }}$ Ed.). California, USA: Elsevier Academic Press.

Constantine, T. (2008). An overview of Ammonia and Nitrogen removal in wastewater treatment. Canada: CH2M HILL.

Eaton, A., Clesceri, L., \& Greenberg, A. (1995). Standard methods for the examination of water and wastewater (19 ${ }^{\text {th }}$ Ed.). Washington, DC: American Health Association.

Eldor, A. P. (2007). Soil microbiology, ecology and biochemistry ( ${ }^{\text {rd }}$ Ed.). Miami, FL: Elsevier Academic Press.

Essington, M. E. (2004). Soil and Water Chemistry. An integrative Approach. Florida, USA: CRC Press.

Fiencke, C., Spieck, E., \& Bock, E. (2005). Nitrifying Bacteria. In D. Werner \& W. E. Newton (Eds.), Nitrogen fixation in Agriculture, Forestry, Ecology, and the Environment (255-276 pp.). Netherlands: Springer.

Garza, Y., Mata, J. C., Barbosa, L. C., \& Rodríguez, J. (2001). Aislamiento y caracterización biodegradativa de microorganismos presentes en un lodo anaerobio. México: Universidad Autónoma de Coahuila. Recuperado de http://www.smbb.com.mx/congresos $\% 20$ $\mathrm{smbb} /$ veracruz01/XIV_fisiolybioqmicroycel.html

Helmer, R., \& Hespanhol, I. (1997). Water Pollution Control: A guide to the use of water quality management principles. London, UK: UNESCO/WHO/UNEP.

Hu, B. L., Zheng, P., Wu, X. Y., \& Yin, L. (2005). Identification of ammonia oxidation Streptomyces strain A2 and study of its autotrophic ammonium oxidation characteristics. Act of Clinical Microbiology, $45(3), 321-4$

Jarpa, M., Aguilar, A., Belmonte, M., Decap, J., Abarzúa, M., \& Vidal, G. (2007). Determinación de la capacidad nitrificante de un sedimento marino proveniente de un centro de cultivo de salmones. Interciencia, $32,679-685$.

Kanehisa Laboratories. (2013a). Kegg Pathway: Nitrogen metabolism: Aeromonas hydrophila subsp. hydrophila ATCC 7966. Retrieved from http://www. kegg.jp/kegg-bin/highlight_pathway?\%20Scale\%20 $=1.0 \&$ map $=$ aha00910\&keyword $=$ Ammonia
Kanehisa Laboratories. (2013b). Kegg Pathway. Nitrogen metabolism: Sphingomonas wittichii. Retrieved from http://www.kegg.jp/kegg-bin/ highlight_pathway?\%20Scale=1.0\&map $=$ swi00910 \&keyword=Ammonia

Madigan, M., Martinko, T., Dunlap, J. M., \& Clark, P. V. D. P. (2009). Brock Biología de los Microorganismos $\left(12^{\text {th }}\right.$ ed). Madrid, Spain: Pearson Education.

Moat, A. G., Foster, J., \& Spector, M. (2002). Microbial Physiology ( $4^{\text {th }}$ Ed.). New York, USA: Wiley-Liss.

Mohan, S. B., Schmid, M., Jetten, M., \& Cole, J. (2004). Detection and widespread distribution of the nrfA gene encoding nitrite reduction to ammonia, a short circuit in the biological nitrogen cycle that competes with denitrification. FEMS Microbiology Ecology, 49, 433-443.

Obaton, M., Amarger, N., \& Alexander, M. (1968). Heterotrophic nitrification by Pseudomonas aeruginosa. Archives of Microbiology, 63, 122-132.

Okpokwasili, G., \& Eleke, F. (1997). Effect of antimicrobial agents on the activity and survival of Aeromonas hydrophila and nitrifying bacteria in vitro. Journal of Natural Science Council of Sri Lanka, 25(4), 231-240.

Park, W., Nam, Y., Lee, M., \& Kim, T. (2009). Anaerobic ammonia-oxidation coupled with $\mathrm{Fe}^{3+}$ reduction by an anaerobic culture from a piggery wastewater acclimated to $\mathrm{NH}_{4}^{+} / \mathrm{Fe}^{3+}$ medium. Biotechnology and Bioprocess Engineering, 14, 680-685.

Spieck, E. \& Bock, E. (2005). The Proteobacteria, Part Introductory Essays. In G. Garrity (Ed.), The lithoautotrophic nitrite-oxidizing bacteria. Bergey's Manual of Systematic Bacteriology (pp. 149-153). New York, USA: Springer.

Templeton, M., \& Butler, D. (2011). Introduction to Wastewater Treatment. UK: Imperial college London and University of Exeter, Ventus Publishing Aps.

Wehrfritz, J. M., Carter, J. P., Spiro, S., \& Richardson, D. J. (1997). Hydroxylamine oxidation in heterotrophic nitrate-reducing soil bacteria and purification of a hydroxylamine-cytochrome c oxidoreductase from a Pseudomonas species. Archives of Microbiology, 166, 421-424.

Werner, D., \& Newton, W. E. (2005). Nitrogen fixation in Agriculture, Forestry, Ecology and the Environment. Netherlands: Springer.

Witzel, K., \& Overbeck, H. (1979). Heterotrophic nitrification by Arthrobacter sp. (strain 9006) as influenced by different cultural conditions, growth state and acetate metabolism. Archives of Microbiology, 122, 137-143.

Zhang, J., Wu, P., Hao, B., \& Yu, Z. (2011). Heterotrophic nitrification and aerobic denitrification by the bacterium Pseudomonas stutzeri YZN-001. Bioresource Technology, 102, 9866-9869. 